\title{
QUEEN'S
UNIVERSITY
BELFAST
}

\section{Risking peace in the 'War against the Poor'? Social exclusion and the legacies of the Northern Ireland conflict}

Tomlinson, M. (2016). Risking peace in the 'War against the Poor'? Social exclusion and the legacies of the Northern Ireland conflict. Critical Social Policy, 36(1), 104-123. https://doi.org/10.1177/0261018315609047

\author{
Published in: \\ Critical Social Policy
}

\section{Document Version:}

Peer reviewed version

Queen's University Belfast - Research Portal:

Link to publication record in Queen's University Belfast Research Portal

Publisher rights

(c) The Author(s) 2015.

\section{General rights}

Copyright for the publications made accessible via the Queen's University Belfast Research Portal is retained by the author(s) and / or other copyright owners and it is a condition of accessing these publications that users recognise and abide by the legal requirements associated with these rights.

Take down policy

The Research Portal is Queen's institutional repository that provides access to Queen's research output. Every effort has been made to ensure that content in the Research Portal does not infringe any person's rights, or applicable UK laws. If you discover content in the Research Portal that you believe breaches copyright or violates any law, please contact openaccess@qub.ac.uk. 


\title{
Risking Peace in the 'War against the Poor'? Social exclusion and the legacies of the Northern Ireland conflict ${ }^{1}$
}

\section{MIKE TOMLINSON}

Queen's University Belfast, Northern Ireland

\begin{abstract}
Discourses around poverty, dependency and austerity take a particular form when it comes to Northern Ireland which is seen as ripe for economic 'rebalancing' and public sector reduction. The Welfare Reform Act 2012 is pivotal in that it provides the muscle for disciplining claimants for a low-waged, flexible labour market. But the Northern Ireland Assembly has not passed the Act or agreed a budget and the return of Direct Rule beckons as a result. The article sheds light on the stand-off over the Welfare Reform Act using data from the 2012 PSE Survey. It demonstrates that the impact of violent conflict is imprinted on the population in terms of high rates of deprivation, poor physical and mental health, and significant differences between those experiencing little or no conflict, and those with 'high' experience. In ignoring these legacies of the conflict, the Westminster government is risking peace in its 'war against the poor'.
\end{abstract}

Key words: benefit sanctions, poverty, violence, welfare reform,

\section{Poverty and Northern Ireland}

On both sides of the Atlantic, poverty has been a focal point in the politics of the 2008 financial crisis and subsequent austerity-driven policies. While this is not the first period in which the 1960s War on Poverty has become a 'war against the poor' (Katz, 1989; Gans, 1995), the stereotyping and labelling of those at the sharp end of the recession has intensified. The term 'welfare' no longer carries positive connotations of well-being and security, but is now used pejoratively to denote the perverse 'choice' of an underclass that prefers state dependency to work (Daly, 2011: 4), or worse, the criminalized status of 'welfare queen' (Gustafson, 2011) with a starring role in the 'poverty porn' industry (Jensen, 2014). There has been a marked change in social attitudes towards benefit recipients, especially long-term sick and disabled people, reflecting 'the success of a long-term campaign of vilification' (Dorling, 2014: 112).

In Britain, the practice of blaming and stigmatizing the behaviours of working age people living in poverty is driven by the political sponsors of 'austerity economics' and 
'welfare reform', and their tabloid press cheerleaders (Clarke and Newman, 2012; Levitas, 2012). This is principally a Westminster government agenda and it is evident that the 'war against the poor' plays badly in the devolved entities of Scotland, Wales and Northern Ireland (see McCormick, 2013), with some nationalist parties forming an explicitly anti-austerity alliance. The Scottish Government's anti-poverty strategy, for example, not only sees the issue as one of Scottish control (or lack of) over taxes and benefits, but also refers specifically to 'the damage being done by welfare reform' (Scottish Government, 2013: 4). Similarly, the Welsh Government has identified 'mitigating the impacts of welfare reform' as one of its key anti-poverty priorities (Welsh Government, 2015: 26).

In Northern Ireland, the devolved government is split over Westminster's economic and social policies. This is most clearly manifest in the political disagreement over the Welfare Reform Act 2012 which, given that social security law is devolved, needs to be passed by the Northern Ireland Assembly whether amended or not. Up to the May 2015 general election, the Welfare Reform Act still did not apply in Northern Ireland. Put simply, the unionist parties support the Welfare Reform Act and are less inclined to be critical of austerity, while the nationalist parties and the Green Party are opposed. Sinn Féin has led the opposition to the Welfare Reform Act and is being widely criticised for threatening the viability of the Northern Ireland Executive.

While the largest cuts to benefits and tax credits came initially from changes in uprating, the Welfare Reform Act 2012 is pivotal in that it introduces a tough disciplinary claimant regime designed to ensure 'correct' claimant choices in a low waged flexible labour market (Wiggan, 2012; Garthwaite, 2011). This led to an immediate increase in the number of benefit sanctions across Great Britain (GB), affecting young people, disabled people and lone parents in particular (Work and Pensions Committee, 2014a; Scottish Government, 2014). The Act further reinforces cuts in long-term sickness and disability benefits (Cross, 2013; Harwood, 2014) and provides the muscle (through benefit sanctions) to enforce whatever reductions in benefits and tax credits are required to deliver on the 'welfare cap' - a limit on the total amount that governments can spend on certain social security benefits in the five years from 2015/16 (Rhodes and Mclnnes, 2014). According one assessment, Northern Ireland is 'much harder' hit by Coalition welfare reforms than other parts of the UK, losing an estimated $£ 750$ million per year by $2014 / 15$ or a loss of $£ 650$ per year per working age adult (Beatty and Fothergill, 2013). The combination of changes to incapacity benefit and Disability Living Allowance (not implemented) are responsible for 
most of the gap. Further, given that women in Northern Ireland derive 22 per cent of income from benefits compared to 9 per cent for men (Potter, 2014), there are clear indications that 'welfare reform' and public sector cuts amount to 'a significant loss of social protection for women' (Hinds, 2011: 125).

\section{Cuba in the United Kingdom (UK)?}

The discourses around austerity, poverty and dependency take a particular form in the context of Northern Ireland. First, the narrative of dependency shifts from the social pathology of individuals to the economic and political pathology of the entire entity. In the conventional wisdom, Northern Ireland is an 'unbalanced realm', 'propped up by a huge subsidy from the rest of the UK', raising public expenditure 'to the equivalent' of 74 per cent of Gross Domestic Product (Northern Ireland Economic Reform Group, 2010: 15). In Daily Mail speak, Northern Ireland is worse than 'the last communist country in the Western hemisphere' (Cuba) where a mere 60 per cent of the economy is state funded (Mail Online, 2009).

In addition to addressing the intrinsic weaknesses of the private sector, 'privatizing peace' (Horgan, 2006) and delivering public sector cuts (Horgan and Gray, 2012), two specific proposals are generally advanced for 'rebalancing' the Northern Ireland economy away from the public sector. The first is to reduce corporation tax to the rate applicable across the border in the Irish Republic (12.5 per cent). This was rejected under the last Labour Government because the initial costs in lost revenues would not be recovered 'in a reasonable period of time' (Varney Report, 2007: 4). Revived under the Coalition Government (HM Treasury, 2011), the proposal was discussed for two years before Prime Minister David Cameron postponed any decision on the matter until after the 2014 Scottish referendum. Whatever the complexities of the issue (Tomlinson and Kelly, 2011: 18-20) the Treasury would be obliged under European law to remove the equivalent net foregone tax from Northern Ireland's block grant (estimates vary from £250-400m per year). This brings us to the second proposal for rebalancing the economy away from public expenditure. The main argument is that the proposed corporation tax-break would be paid for, eventually, from extra tax revenues and savings on social security expenditure. Attracted by the low tax rate and the ready supply of unemployed and inactive labour, new foreign direct investment would create up to 90,000 new jobs. In one model, a quarter of new jobs are filled by the unemployed and three-quarters by the inactive (Northern Ireland Economic Reform Group, 2010: 61), aided and abetted by welfare reforms (HM Treasury, 2011: 14). 
This scenario has been rudely interrupted not only by the politics of Scottish devolution but also by the failure of the Northern Ireland Assembly to pass the enabling legislation to implement the core provisions of the 2012 Welfare Reform Act. This 'noncompliance' means that the Treasury is imposing 'fines' by way of deductions to the block grant $-£ 87 m$ in $2014 / 15$ and $£ 114 m$ in $2015 / 16$. A charge for the maintenance of legacy computer systems is also threatened. This political stand-off and its public expenditure consequences have fanned a great deal of commentary and debate, with some speculating about the return of Direct Rule and even, according to one prominent unionist politician, that 'the men of violence will move quickly to fill the vacuum created by a failure of political leadership' (Donaldson, 2014).

The increasing politicisation of devolution at country and English regional levels is stimulating growing attention to regional accounts and 'fiscal deficits'. The Centre for Economics and Business Research (CEBR), for example, represents the countries and regions of the UK in terms of the 'scale of subsidies' flowing from London and the South East to other parts of the UK - 'one pound in five earned in London subsidises the rest of the UK' (CEBR, 2012). In the case of Northern Ireland, the 'deficit' between estimated tax receipts and expenditure amounts to 39 per cent of Gross Domestic Product (GDP), compared to 10 per cent for the UK as a whole (2010/11 figures), suggesting that Northern Ireland receives a net subsidy of 29.4 per cent of its GDP. This reinforces the argument of unionists that the grossly indebted Irish Republic cannot possibly afford a united Ireland (McGimpsey, 2009).

This calculus of subsidy has been described as 'a carefully calibrated fiction' (Massey, 2013: 2). It is far removed from both a needs-based analysis and from traditional principles of resource allocation designed to achieve the same standards of public service provision throughout a United Kingdom. It is also reflective of a growing English nationalism in public spending debates (Tomlinson, 2002). But whatever its lack of merits, the 2010-15 Coalition's policy choices worsened the position. Relative to Gross Value Added (GVA, a proxy for GDP), estimated aggregate public expenditure in Northern Ireland had reached 82 per cent by $2011 / 12$ compared to 68 per cent in $2007 / 08$, immediately prior to the recession. Over the same period GVA went down by 11.8 per cent in real terms and real average incomes fell by 12.1 per cent from 2008 to 2011 (derived from Office of National Statistics, 2013 and Department of Finance and Personnel, 2014). By 2012/13, the median household income (after housing costs) was still 4 per cent below the level in 2002/03 (Tomlinson, Hillyard and Kelly, 2014). 
To put this into perspective, Northern Ireland is one of 29 European Union NUTS2 Regions recording a fall in GDP per capita (standardised to purchasing power standards) relative to the EU-28 average between 2008 and 2011 of more than -5 percentage points: the figure was -10.6. Seven other regions of the UK exceeded -10.0 and in Ireland, the Border, Midland and Western region fell by -5.3 . In the thirteen regions of Greece, the average regional fall was -12.2 (ranging from -4.7 to -19.1 ), whereas every region of Germany improved its position - in eight cases by more than 10 percentage points (Eurostat, 2014).

From the published estimates, it is evident that taxation has become more regressive. Total Northern Ireland revenues in 2011/12 were 6.1 per cent below 2007/08 levels in real terms, but corporation tax declined by 37 per cent, wealth taxes by 63 per cent, and net income tax by 22 per cent. In contrast, Value Added Tax revenues rose by 15 per cent, accounting for 24 per cent of all tax revenue by 2011/12. The tax take on alcohol, tobacco and gambling rose by 26 per cent in real terms (all figures derived from Department of Finance and Personnel, 2014 and HM Revenue \& Customs, 2014).

But there are several reasons for questioning the wilder claims of the dependency thesis. First, the private sector accounts for 74 per cent of Northern Ireland's total GVA as measured under the Northern Ireland Composite Economic Index (Department of Enterprise, Trade and Investment, 2014). In terms of employment, Northern Ireland's private sector employment rate is not the worst in the UK. It is the fifth lowest of the 37 NUTS2 regions of the UK: the West Midlands and Merseyside were two of the four areas with lower rates in 2011 (Prothero, 2011: 19). Nor is Northern Ireland's public sector employment rate the highest. In 2011, it was the eleventh highest, just 1.4 percentage points above the overall UK rate of 17.7 (Prothero, 2011:21). Northern Ireland's non-employment rate (combining unemployment and inactivity) at 34.9 per cent was lower than West Midlands (38.2), Merseyside (36.0) (and two other areas), and not so far off Greater Manchester at 34.0.

Furthermore, representations of 'fiscal deficit' are based on public accounts, ignoring public/private and other financial flows, and the hidden transfers from poorer regions to the richest. The costs of corporate welfare, both routine and related to the banking crisis, that involve 'privatizing gains and socializing losses' (Engelen et al, 2011: 13) of the, at times criminal, failings of financial institutions, are largely borne by everywhere outside of London and South East - a 'metropolitanisation of gains and a 
nationalisation of losses' (Leaver, 2013). London sucks in graduates, public and private revenue streams - London receives over four-fifths of PFI/PPP revenue (Chakrabortty, 2014) - and benefits exclusively from the majority of large infrastructure projects. Northern Ireland has become more exposed to this process as the closed 'workhouse economy' of the 1970s and 1980s (Rowthorn and Wayne, 1988: 99) opened up to external private investment, including around $\$ 2$ billion US direct investment between 1994 and 2005 (Portland Trust, 2007).

\section{Threats to peace?}

The political impasse over the Welfare Reform Act in Northern Ireland reflects two distinct positions with regard to those social excluded form the labour market and classified as 'inactive'. On the one hand, Northern Ireland's traditionally high inactivity rate, typically 5-6 percentage points above the rate in Great Britain, is seen as an exploitable labour reserve that can be drawn into productive employment with a little encouragement from benefit sanctions. Such a policy is seen as economically desirable and apparently free of political risks (see Hansard, 2 April 2014, col. 868). On the other hand, a high proportion of inactivity is comprised of long-term sickness and disability, with a growing body of argument that this is related to political violence in the past (Horgan, 2006: 661). In Northern Ireland's workless households, 36.4 per cent are sick or disabled compared to 28.5 per cent in Wales and 27.7 in the UK as a whole (Office of National Statistics, 2014).

There is also concern over the numbers of young people who are detached from employment. The employment rate for 18-24 year olds declined by 11.5 percentage points between 2007 and 2012, whereas it rose for all other age groups (derived from Labour Force Survey). According to one assessment, almost a quarter of young working class Protestant males are unemployed compared to one in six Catholics, which is 'a seedbed for trouble' (Nolan, 2014: 13). Similarly, the Shadow Secretary of State for Northern Ireland warns that 'the political situation in Northern Ireland is at its most fragile for many years'. Austerity has 'undermined the economic peace dividend people were promised' and 'people are at risk of exploitation by paramilitary organisations and political extremists' (Lewis, 2014).

The 2012 UK Poverty and Social Exclusion (PSE) Survey is uniquely placed to address the issue of how social needs in Northern Ireland have been shaped by the impact of 
violent conflict on individuals and families. Specifically, it provides data which shed light on employment status, long-term sickness and disability, and mental health.

\section{The 2012 PSE Survey: impact of conflict}

The 2012 PSE Survey (see poverty.ac.uk for further details about the study aims and methodology) used the same questionnaire across the UK except that the Northern Ireland survey included a special 'Troubles' module designed to measure individual experience of the conflict. Based on the most common conflict-related events and the patterns of violence over thirty years, the 'Troubles' module asked questions on people's experience of death and injury of close friends and relatives, and of witnessing violent events, such as gunfire, bomb explosions, rioting and physical assaults. There were questions on house searches carried out by the police or army, and on whether people had had to move house or a job because of attack, intimidation, threats or harassment. People were asked whether they, or anyone they knew had spent time in prison because of the conflict. They were also asked to think about the worst thing that had happened to them 'because of the Troubles' and to say when this was. Finally they were asked if they had followed up the worst experience by taking action of some kind, such as joining a support group or seeing their doctor (see Tomlinson, 2013). This module was included because there is very little populationwide data on the prevalence and impact of conflict-related events, and none which includes data on the broad range of social circumstances covered by the PSE study (except the first Northern Ireland PSE study, Hillyard et al, 2003). 'Victim and survivor' issues are central to unresolved political questions, such as those explored under the Haass/O'Sullivan negotiations (2013), but they are rarely informed by prevalence data (see also Eames/Bradley, 2009).

It is possible to construct many measures of poverty from the 2012 PSE Survey. These include the familiar 'relative income' measure of households and individuals living below 60 per cent of the median income, which can also be based on different values for 'equivalisation' (see Hillyard et al, 2003: 35-37); a deprivation measure based on a lack of essential items; 'subjective poverty' derived from participants own perception of whether they are 'poor' now or have lived in poverty in the past; and measures such as the 'PSE poor' which combine deprivation with low income. The latter is based on items which the majority of the population perceive to be basic necessities and is known as the 'consensual' measure of poverty (see Mack and Lansley, 1985 and 2015; Gordon, 2006; Nandy and Pomati, 2014). 
The Northern Ireland survey involved re-contacting 1,702 of the 2,484 households who took part in the Northern Ireland Family Resources Survey between January 2010 and March 2011, and where at least one adult had agreed to be contacted for a follow-up study. Interviews were carried out with 988 households and 1,433 individuals.

The Northern Ireland 'Troubles' module was placed at the end of the 2012 PSE Survey in a self-completion section that also included questions on national identity, political preferences and religion. Following self-completion questions on mental health, household responsibilities, domestic violence, crime, homelessness and so on, the Northern Ireland participants were faced with the following statement:

The next set of questions is about your experience of the Troubles. This includes questions about physical injury you personally experienced or the injury or death to a close friend or relative. Questions about imprisonment are also included. If you feel uncomfortable answering these questions, then you do not need to answer them. All answers will be kept strictly confidential.

Are you willing to answer questions about your experience of the Troubles?

At this point, around one fifth of the remaining participants declined to answer the questions on 'experience of the Troubles', leaving 1,165 who did. Among 18-24 year olds 37.6 per cent declined the 'Troubles' questions whereas the age groups who had lived through most of the years of violence had a much lower refusal rate $(11.2 \%$ for 55-64 year olds and $15.7 \%$ for $45-54$ year olds). Catholics were more likely not to answer the questions than Protestants (24\% to $17 \%$ refusal rates).

Men were more likely than women to have experienced conflict-related events. In twelve out of thirteen events for which the difference was measurable (requiring a minimum cell size of 35 cases) the difference was statistically significant. Out of fourteen measurable items, Protestants were slightly more likely than Catholics to have experienced three events but the difference was not statistically significant for any of these. Catholics were more likely to experience an event in the remaining eleven items and for seven of these the difference was statistically significant. The survey found that overall, 9.2 per cent of adults had had their homes searched by the police or army. But Catholics were 4.3 times more likely than Protestants to have had their house searched and twice as likely to have had a close relative in prison. 
For every measure of poverty - deprivation, relative income, combined deprivation and income, and subjective measures - those in poverty were less likely to answer the 'Troubles' questions. Nevertheless, there was a clear link between specific conflict experience and higher deprivation rates (lacking three or more items because they cannot be afforded, see Table 1) compared to the overall rate for all adults answering the 'Troubles' questions. As Table 1 shows, the overall rate for those adults lacking three or more of 22 deprivation items is 26 per cent but the rate is more than double (58\%) for those who moved house due to attack, intimidation, threats or harassment.

Table 1: Deprivation rates for conflict-related events

\begin{tabular}{|l|c|}
\hline Cannot afford 3 or more out of 22 necessities & $\begin{array}{c}\% \text { of } \\
\text { adults }\end{array}$ \\
\hline All adults & 26 \\
\hline Close friend killed & 36 \\
\hline Close relative killed & 38 \\
\hline Witnessed an assault & 43 \\
\hline Close relative was in prison & 45 \\
\hline House searched by police or army (at least once) & 56 \\
\hline Moved house due to attack, intimidation, threats or harassment & 58 \\
\hline
\end{tabular}

Of 21 conflict-related events, 14 proved to be statistically significant in raising the risk of a longstanding illness or disability. Taking relatively common events such as rioting and bomb explosions, witnessed by a third or more of the adult population, the survey found that the risk of a longstanding illness or disability was at least 1.3 times higher than for those who had no experience of such events. Those that had had to move house were 1.8 times as likely to report a longstanding illness or disability (see Table 2). 
Table 2: Risk of longstanding illness or disability, relative to those with no experience

\begin{tabular}{|l|l|}
\hline Conflict-related event & Risk ratio \\
\hline Moved house due to attack, intimidation, threats or harassment & 1.8 \\
\hline House searched by police/army & 1.7 \\
\hline Close friend killed & 1.6 \\
\hline Close friend in prison & 1.6 \\
\hline Witnessed gunfire & 1.5 \\
\hline Injury to self & 1.5 \\
\hline Someone else injured & 1.5 \\
\hline Someone else killed & 1.5 \\
\hline Witnessed bomb explosion & 1.4 \\
\hline Witnessed assault & 1.3 \\
\hline Close relative injured & 1.3 \\
\hline Witnessed rioting & 1.3 \\
\hline Witnessed other serious violence & 1.3 \\
\hline
\end{tabular}

The survey found that 30 per cent of adults had no experience at all of the conflictrelated events included the PSE survey. For the remaining 70 per cent, the median number of events experienced was three. In order to explore differences between those with no experience of conflict-related events and those with 'high' experience, various bandings were explored, the challenge being to balance sufficient numbers for statistical analysis with meaningful break points in the data. The 'high' threshold was set at five or more conflict-related events and this captured 18.9 per cent of the adult population. Compared to all adults, this group was 2.7 times as likely to have reported 'a close relative was killed', 3.4 times that 'a close relative was injured', 3.5 times as likely to experience a house search and 3.4 times as likely to have witnessed gunfire. All of those who said a close relative was in prison due to the 'Troubles' and all of those who had been forced to move house, fell into this band. The 'low' experience band was set at one or two conflict-related events. This band includes no-one with a close relative injured, less than ten per cent 'close relative killed' and 'witnessed gunfire', and only two per cent in the band had experienced a house search. This leaves a 'moderate' experience band (three or four events experienced) comprising 19 per cent of adults. In the moderate group nearly a half had witnessed a bomb explosion, a quarter an assault, nearly one third gunfire and 13 per cent had a close relative injured and had experienced at least one house search. 
We can see from Table 3 that 46.4 per cent of those with 'high' conflict experience have a long-standing illness or disability compared to a rate of 23.0 per cent for those with no experience. Most striking is the difference in rates for poor mental health: those with high conflict experience are 2.65 times as likely to be at risk of mental illness. This 'risk' is based on the 12 question version of the General Health Questionnaire (GHQ12) which was included in the survey. It is an established convention to regard a score of four or more on GHQ12 as indicative of mental illness (Goldberg and Williams, 1988).

Table 3: Self-reported health status by experience of Troubles

\begin{tabular}{|l|l|l|l|}
\hline Percentage of adults & \multicolumn{3}{|c|}{ Experience of conflict-related events } \\
\hline & \multicolumn{1}{|c|}{ None } & \multicolumn{1}{c|}{ High } & $\begin{array}{c}\text { Ratio } \\
\text { High/None }\end{array}$ \\
\hline Long-standing illness or disability & 23.0 & 46.4 & 2.02 \\
\hline Health 'bad' or 'very bad' & $5.1^{*}$ & 14.9 & 2.92 \\
\hline Health 'good' or 'very good' & 77.8 & 57.1 & 0.73 \\
\hline Mental health: GHQ12 score of 4 or more & 14.7 & 38.9 & 2.65 \\
\hline
\end{tabular}

${ }^{*}$ Not reliable due to small cell size

The results for 'overall life satisfaction' are shown in Table 4. The question used in the PSE study was one of the four new 'happiness questions' added to the Great Britain Integrated Household Survey in April 2011, reflecting both political and scientific interest in 'well-being' (Tomlinson and Kelly, 2013). Those with high conflict experience have an average life satisfaction score on a par with all disabled people (UK), slightly above the unemployed and divorced/separated, and well above those classified as inactive in the labour market for reasons of long-term sickness.

Table 4: Average 'life satisfaction' scores

\begin{tabular}{|r|r|r|c|}
\hline \multicolumn{1}{|c|}{ ONS } & $\begin{array}{c}\text { Average } \\
\text { score }\end{array}$ & PSE & $\begin{array}{c}\text { Average } \\
\text { score }\end{array}$ \\
\hline 2011-12: & & 2012: & \\
\hline Northern Ireland & 7.41 & All Northern Ireland & 7.36 \\
\hline Disabled (UK) & 6.75 & 'Troubles' experience: None & 7.85 \\
\hline Unemployed (UK) & 6.47 & Low & 7.47 \\
\hline Divorced/separated (UK) & 6.67 & Moderate & 7.37 \\
\hline Inactive, long-term sick (UK) & 5.67 & High & 6.75 \\
\hline
\end{tabular}

Source: Office of National Statistics (2012) 
Cleary, it is important to consider how age relates to the above patterns. Figure 1 compares the rate of 'Troubles' experience for 'none' and 'high' within the different age bands. The graph describes a 'Troubles' cohort comprising people who were in their late 40 s to late 50 s in 2012 , or between 6 and 16 in 1970 when the violence and killings escalated (the highest death toll was in 1972 - 497 killed). This is the same cohort implicated in the doubling of Northern Ireland's suicide rate since 1998 (Tomlinson, 2012). Using logistic regression, we find that the $45-54$ age band is 4.9 times as likely to have a moderate or high 'Troubles' experience score compared to the 18-35 age band, based on a model that controls for gender, religion and household type. Each of these variables has a significant independent effect on 'Troubles' experience.

Figure 1: Rates of 'Troubles' experience (None/High) by age bands

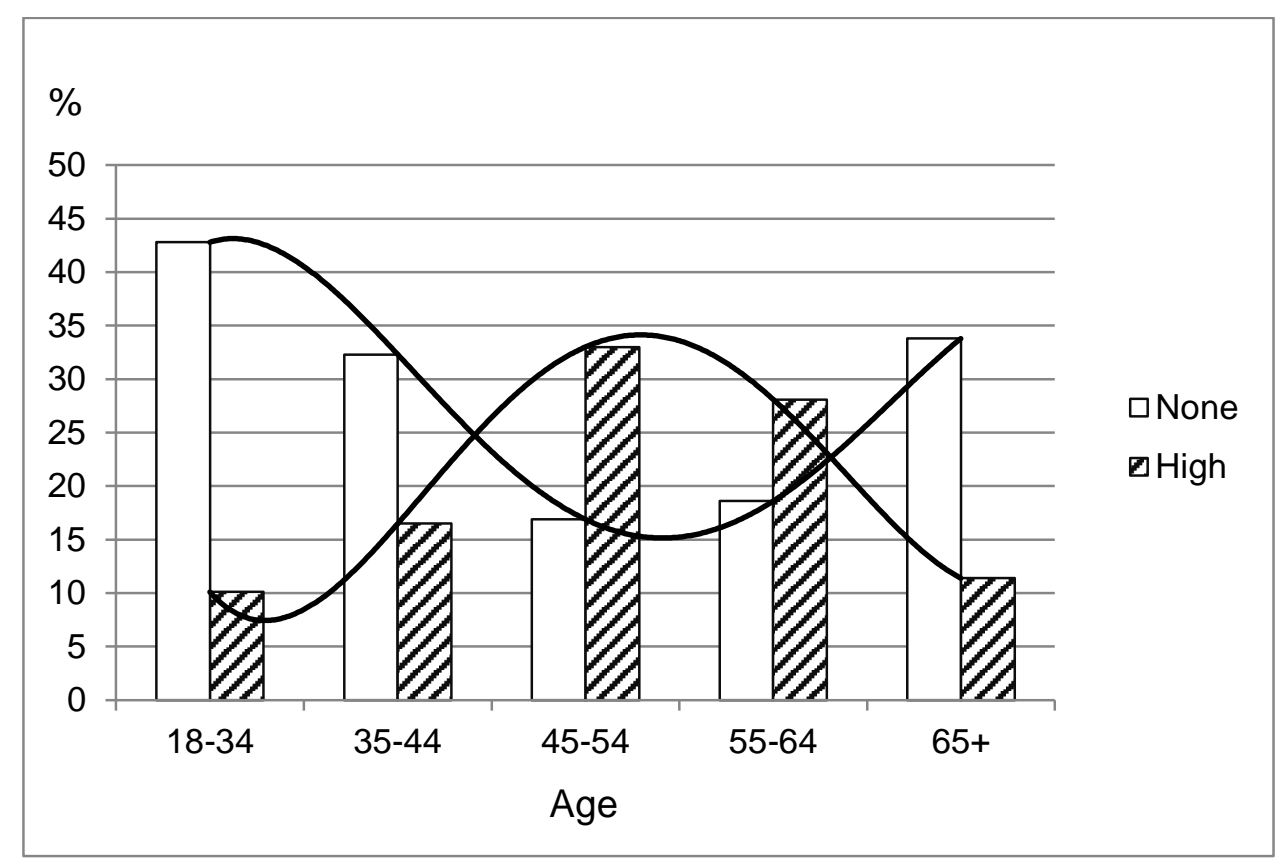

'Troubles' experience is more strongly related to poor health than poverty as a comparison of Tables 3 and 5 shows. Those with high 'Troubles' experience are 1.85 times as likely to have lived in poverty in the past, 1.16 times as likely to say they are poor 'sometimes' or 'all the time', and 1.76 times as likely to be lacking three or more deprivation items (out of 22) because they are unable to afford them. When income is brought into the picture, the relationship between poverty and 'Troubles' experience breaks down. There is a slight gradient from low to high 'Troubles' experience for the income-based PSE 'at risk of poverty' measure but the 'none' group have a worse poverty rate than the 'high' group as Table 5 shows. 
Table 5: Poverty rates by experience of 'Troubles'

\begin{tabular}{|l|c|c|c|}
\hline Percentage of adults & \multicolumn{3}{|c|}{ Experience of conflict-related events } \\
\hline & None & High & $\begin{array}{c}\text { Ratio } \\
\text { High/Low }\end{array}$ \\
\hline Poor 'sometimes' / 'all the time' & 32.4 & 37.6 & 1.16 \\
\hline Lived in poverty at some point in the past & 24.2 & 44.7 & 1.85 \\
\hline $\begin{array}{l}\text { Deprivation, lacking 3 or more items } \\
\text { (unaffordable) }\end{array}$ & 19.7 & 34.6 & 1.76 \\
\hline PSE poverty & 20.7 & 20.6 & 1.00 \\
\hline $\begin{array}{l}\text { Income poverty (<60\% median income, PSE } \\
\text { equivalisation) }\end{array}$ & 27.4 & 23.7 & 0.87 \\
\hline
\end{tabular}

Adding deprivation to the logistic regression model mentioned above, we find that the 45-54 age band is now over five times as likely to have moderate or high 'Troubles' experience compared to the youngest age band, controlling for the other factors. Independently (and controlling for all the other factors), deprivation increases the likelihood of moderate or high 'Troubles' experience by a factor of 1.8 , religion by a factor of 1.4 , and gender by a factor of 2.5 .

\section{A strategy of mass distress}

While it was the last Labour Government that introduced the Work Capability Assessment (WCA) for all existing and new sick and disabled claimants (Harrington, 2010), this group became a particular focus for the 2010-15 Coalition Government which targeted working age benefits in terms of value, eligibility and sanctions. The reassessment of existing Incapacity Benefit claimants in Great Britain began in October 2010 and by December 2013, over one and a quarter million claimants had been reassessed, with 20 per cent of these (a quarter of a million) being deemed 'fit for work' and a further 43 per cent placed in the Employment Support Allowance (ESA) 'work related activity group' (Department for Work and Pensions, 2014a). New claimants have fared less well with 52 per cent having their claims rejected as they were deemed fit for work (up to December 2013). The process has been surrounded in controversy from early on, particularly because of the 'stressful and anxiety-provoking experience' of the WCA, with the Work and Pensions Committee stating that 'the flaws in the ESA system are so grave... a fundamental redesign of the ESA end-to-end process is required' (Work and Pensions Committee, 2014b: 3-4; see also The Big Issue, 2014). 
Those not eligible for ESA must turn to Jobseeker's Allowance (JSA) where, as the Child Poverty Action Group (CPAG) points out, 'the punitive campaign by DWP ministers and officials has continued to intensify' (CPAG, 2014: 2). In October 2010, 52 per cent of sanction referrals resulted in an adverse decision; the rate exceeded 65 per cent by early 2014. From October 2012 up to June 2014, 834,000 adverse sanctions were applied under JSA (including stopping benefit payments) and 171,000 of these were applied to people with disabilities (Department for Work and Pensions, 2014a). The rate of sanctioning has risen to 6.46 per cent of all claimants per month. ESA claimants are also sanctioned and this rate is increasing, albeit from a lower base of 1,091 for the month of December 2012 up to 5,132 for June 2014 (Department for Work and Pensions, 2014a).

The Welfare Reform Act applies a similar process of reassessment to every one of the 3.2 million claimants of Disability Living Allowance (DLA) who are being reassessed for Personal Independence Payment (PIP) from October 2013. In the Coalition Government's 'emergency' budget of June 2010, well before any new assessment process had been announced, the change to PIPs was predicted to result in a 20 per cent cut in spending (Kennedy, 2010). Up to July 2014, 72 per cent of the 39,000 reassessed DLA claims resulted in a PIP award $(79 \%$ if withdrawn claims are excluded). Of the 490,400 new claims for PIP, only 55 per cent have been awarded (Department for Work and Pensions, 2014b: 12-15).

With the exception of the reform of DLA under the Welfare Reform Act, sick and disabled claimants in Northern Ireland have experienced a similar process of reassessment as claimants in Britain. The result is an eight per cent decline in the total number of IB/ESA claimants in Northern Ireland over the three years from May 2011 (Department for Social Development, 2014: 16) compared to a 3.9 per cent decline in GB. The total working age claimant numbers, however, declined by very little (1.2\%) during this time, whereas the GB decline over the same period was 9.8 per cent, reflecting a 30 per cent decline in unemployed claimants in GB. The big difference in claimants between Northern Ireland and GB is revealed in Table 6 which shows the proportion of claimants relative to the working age population. In the case of the main sickness/disability benefit, the Northern Ireland rate is 1.52 times the GB rate, and for DLA it is more than double. 
Table 6: Working age claimants as a proportion of working age population, May 2014

\begin{tabular}{|l|c|c|c|}
\hline \% of working age population & $\begin{array}{c}\text { Great } \\
\text { Britain }\end{array}$ & $\begin{array}{c}\text { Northern } \\
\text { Ireland }\end{array}$ & $\begin{array}{c}\text { NI/GB } \\
\text { rate ratio }\end{array}$ \\
\hline All working age claimants & 13.0 & 23.2 & 1.79 \\
\hline IB/ESA claimants & 6.2 & 9.4 & 1.52 \\
\hline DLA & $8.3^{*}$ & 17.9 & 2.16 \\
\hline
\end{tabular}

*August 2013

Source: Calculated from DSD and DWP statistics

The reform and reduction of DLA awards poses a more serious threat to claimants in Northern Ireland than elsewhere. Over one in ten of the population received DLA in Northern Ireland (September 2010) compared to around one in thirteen in Wales and one in fifteen in the North East of England. In May 2011, 14 per cent of DLA claimants were in receipt of the benefit for 'mental health causes' (Department for Work and Pensions, 2012). The figure for Northern Ireland at the same time was 23 per cent. On the basis of a UK-wide testing exercise, the estimated impact of DLA reassessment is that one third of Northern Ireland claimants will have a decreased PIP award, compared to 29 per cent in GB. A quarter will receive no award (30\% in GB) and 23 per cent will have an increased award (27\% in GB) (Department for Social Development, 2013).

There is also a marked contrast in DLA awards by the Northern Ireland parliamentary constituencies, ranging from 69 per 1000 people (North Down held by an Independent Unionist) to 206 per 1000 (West Belfast held by Sinn Féin) - or one in five of the population. Across the eight constituencies held by the Democratic Unionist Party (DUP) the rate of DLA was 92 per 1000 population; in the five Sinn Féin constituencies the rate was 127 (Northern Ireland Assembly, 2011).

\section{Conclusion}

The 2012 PSE Survey provides clear evidence of the impact of years of violent conflict on the population of Northern Ireland. Experience of conflict-related events, from witnessing violence to the loss of close friends and relatives, is imprinted on a 'Troubles cohort', an age group that were children and young people at the start of the worst of the violence and killing, though other age groups are also affected. High 
'Troubles' experience more than doubles the risk of mental illness and self-reported poor health and longstanding illness or disability. It substantially increases the risk of deprivation. A fifth of Northern Ireland's children are growing up with an adult who has high 'Troubles' experience and therefore with an adult carrying a 39 per cent risk of a mental illness.

Given such a legacy, we should not be surprised to find the conflict imprinted on the benefits system in the form of high rates of sickness and disability benefit receipt, an area of social security that has been a particular focus for 'welfare reform'. None of this impresses the architects of reform who have divided the world into those who depend on 'welfare' and taxpayers who pay for it, while they pursue a shock doctrine of austerity and inequality, and accelerate a London-centric economy based on financial services which 'subsidises' state-dependent places such as Northern Ireland.

The Coalition largely ignored the distinctive and polarised politics of Northern Ireland and there is every indication that the 2015 Conservative Government will continue in the same way. The assumption is that nationalist and unionist causes are detached from the 'necessary' business of rebalancing the economy and the ambition of reducing the scale of the public sector by an unprecedented degree (Taylor-Gooby and Stoker, 2011). In so doing, they are endangering the governance framework of the Good Friday Agreement and subsequent agreements: they have succeeded in dividing unionists and nationalists over austerity and welfare reform with the threat that it becomes a constitutional issue. The prospect is that social security law will be brought under direct Westminster control, thereby enforcing the Conservative Government's austere economic agenda and anti-poor social policies. Austerity is having a differential impact on women and also risks excluding young people from meaningful participation in the labour market and instead, finding meaning in 'trouble'. The pattern of recent years is that Westminster Governments are prepared to risk peace in their war on the poor.

\section{References}

Beatty, C and Fothergill, S (2013) The Impact of Welfare Reform on Northern Ireland. Belfast: Northern Ireland Council for Voluntary Action.

http://www.nicva.org/resource/impact-welfare-reform-northern-ireland

Centre for Economics and Business Research (2012) Data release, $13^{\text {th }}$ February. http://www.cebr.com 
Chakrabortty, A (2014) 'What's that sucking sound? It's all the public money and private wealth being swallowed up in London'. The Guardian, $10^{\text {th }}$ February.

Child Poverty Action Group (2014) The DWP's JSA/ESA sanctions statistics release, 14 May 2014. Briefing. London: CPAG.

http://www.cpag.org.uk/sites/default/files/uploads/14-

05\%20Sanctions\%20Stats\%20Briefing\%20-\%20D\%20Webster\%20May\%202014.pdf

Clarke, J and Newman, J (2012) 'The alchemy of austerity', Critical Social Policy 32(3): 299-319.

Cross, M. (2013) 'Demonised, impoverished and now forced into isolation: The fate of disabled people under austerity'. Disability and Society 28(5): 719-723.

Daly, M (2011) Welfare. Cambridge: Polity Press.

Department for Social Development (2013) Welfare Reform Bill Section 75 Update.

April 2013.

http://www.equalityni.org/ECNI/media/ECNI/Consultation\%20Responses/2013/DSDwel fare-reform-bill-section-75-update-april-2013.pdf

Department for Social Development (2014) Northern Ireland Benefits Statistics Summary, May 2014. Released, August.

Department for Work and Pensions (2012) Disability Living Allowance Reform, Equality Impact Assessment. May.

https://www.gov.uk/government/uploads/system/uploads/attachment data/file/220151/ eia-dla-reform-wr2011.pdf

Department for Work and Pensions (2014a) Supplementary Tables of Employment and Support Allowance Outcomes of Work Capability Assessments, Great Britain. Release, 11 September.

Department for Work and Pensions (2014b) Personal Independence Payment: Official Statistics, GB. Release, 17 September.

Department of Enterprise, Trade and Investment (2014) NI Composite Economic Index Component Series Bulletin.

Department of Finance and Personnel (2014) Northern Ireland Net Fiscal Balance

Report 2011-12. http://www.dfpni.gov.uk/northern-ireland-net-fiscal-balance-report

Donaldson, J (2014) 'Welfare Reform - The Facts'. Blog, $1^{\text {st }}$ October.

www.jeffreydonaldson.org

Dorling, D (2014) Inequality and the 1\%. London: Verso Books.

Eames/Bradley Report (2009) Report of the Consultative Group on the Past. http://cain.ulst.ac.uk/victims/docs/consultative_group/cgp_230109_report.pdf

Engelen, E, Ertürk, I, Froud, J, Johal, S, Leaver, A, Moran, M, Nilsson, A and Williams, K (2011) After the Great Complacence: Financial Crisis and the Politics of Reform.

Oxford: Oxford University Press. 
Eurostat (2014) GDP at Regional Level. http://ec.europa.eu/eurostat/statisticsexplained/index.php/GDP_at_regional_level\#Changes_in_GDP_per_inhabitant.2C_20 08.E2.80.9311

Gans, H J (1995) The War Against the Poor: The Underclass and Anti-poverty Policy. New York: Basic Books.

Garthwaite K (2011) “The Language of Shirkers and Scroungers?" Talking about Illness, Disability and Coalition Welfare Reform', Disability \& Society 26(3): 369-372.

Goldberg, D and Williams, P (1988) A user's guide to the General Health questionnaire. Windsor, UK: NFER-Nelson.

Gordon, D. (2006) 'The concept and measurement of poverty' in C. Pantazis, D. Gordon, \& R. Levitas (eds), Poverty and social exclusion in Britain: The Millennium Survey. Bristol: The Policy Press.

Gustafson, K (2011) Cheating Welfare: Public Assistance and the Criminalization of Poverty. New York: New York University Press.

Haass, R and O'Sullivan, M (2013) Proposed Agreement 31 December 2013, An Agreement among the parties of the Northern Ireland Executive on parades, select commemorations, and related protests; flags and emblems; and contending with the past. http://www.northernireland.gov.uk/haass.pdf

Harrington, M (2010) An Independent Review of the Work Capability Assessment. London: The Stationery Office.

Harwood, R (2014) "The dying of the light": The impact of the spending cuts, and cuts to employment law protections, on disability adjustments in British local authorities'. Disability and Society 29(10): 1511-1523.

Hillyard, P, Kelly, G, McLaughlin, E, Patsios, D and Tomlinson, M (2003) Bare Necessities: poverty and social exclusion in Northern Ireland. Belfast: Democratic Dialogue.

Hinds, B (2011) The Northern Ireland Economy: Women on the Edge? A Comprehensive Analysis of the Impacts of the Financial Crisis. Belfast: Women's Resource and Development Agency.

HM Revenue \& Customs (2014) A disaggregation of HMRC tax receipts between England, Wales, Scotland \& Northern Ireland. October.

HM Treasury (2011) Rebalancing the Northern Ireland Economy. London: HM Treasury.

Horgan, G (2006) 'Devolution, direct rule and neo-liberal reconstruction in Northern Ireland.' Critical Social Policy 26(3): 656-668.

Horgan, G and Gray, A M (2012) 'Devolution in Northern Ireland: A lost opportunity?' Critical Social Policy 32(3): 467-478.

Jensen, T (2014) 'Welfare Commonsense, Poverty Porn and Doxosophy', Sociological Research Online 19(3). 
Katz, M B (1989) The Undeserving Poor: From the War on Poverty to the War on Welfare. New York: Pantheon Books.

Kennedy, S (2010) June Budget and Spending Review 2010: DLA and ESA changes. Standard Note SN/SP/5749. London: House of Commons Library.

Leaver, A (2013) 'The metropolitanisation of gains, the nationalisation of losses', $25^{\text {th }}$ September. www.opendemocracy.net

Levitas, R (2012) 'The Just's Umbrella: Austerity and the Big Society in Coalition policy and beyond', Critical Social Policy 32(3): 320-342.

Lewis, I (2014) Speech to Labour Party Conference. 22 September. Manchester.

Mack, J and Lansley, S (1985) Poor Britain, London: George Allen \& Unwin.

Mack, J and Lansley, S (2015) Breadline Britain: The Rise of Mass Poverty. London: Oneworld.

Mail Online (2009) 'Welcome to Cuba UK', $29^{\text {th }}$ June.

http://www.dailymail.co.uk/news/article-1196182/Welcome-Cuba-UK-Areas-Britaindependent-state-cash-Castros-nation.html\#ixzz3HF6Xa6HG

Massey, D (2013) 'The ills of financial dominance'. Tax Justice Focus 8(2): 1-3.

McCormick, J. (2013) A Review of Devolved Approaches to Child Poverty. York: Joseph Rowntree Foundation. http://www.jrf.org.uk/sites/files/jrf/child-povertydevolution-full.pdf

McGimpsey, C (2009) 'The absurd quest for a united Ireland', The Guardian. $16^{\text {th }}$ July. Northern Ireland Economic Reform Group (2010) The case for a reduced rate of Corporation Tax in Northern Ireland. Belfast.

Nandy, S. and Pomati, M. (2014) 'Applying the Consensual Method of Estimating Poverty in a Low Income African Setting', Social Indicators Research. DOI $10.1007 / \mathrm{s} 11205-014-0819-z$

Nolan, P (2014) The Northern Ireland Peace Monitoring Report, Number 3. Belfast: Community Relations Council.

Northern Ireland Assembly (2011) An Introduction to Welfare Reform. Research and Library Service Briefing Paper, 14 January.

http://archive.niassembly.gov.uk/researchandlibrary/2011/1311.pdf

Northern Ireland Economic Reform Group (2010) The Case for a Reduced Rate of Corporation Tax in Northern Ireland.

http://ergni.org/reports/report_corporation_tax_may_2010.pdf

Office of National Statistics (2012) Measuring Subjective Well-being in the UK, First Annual ONS Experimental Subjective Well-being Results. Release, 24 July 2012.

Office of National Statistics (2013) Regional Gross Value Added (Income Approach), Release, December. 
Office of National Statistics (2014) People living in workless households, reasons for not working by regions: January-December 2013. Release, $4^{\text {th }}$ November.

Portland Trust (2007) Economics in Peacemaking: Lessons from Northern Ireland. London: Portland Trust.

Potter, M (2014) Review of Gender Issues in Northern Ireland. Belfast: Northern Ireland Assembly Research and Information Service. $28^{\text {th }}$ January.

Prothero, R (2011) Subregional analysis of public and private sector employment. Office for National Statistics.

http://www.ons.gov.uk/ons/dcp171766_241911.pdf

Rhodes, C and McInnes, R. (2014) The Welfare Cap. House of Commons Library, $3^{\text {rd }}$ December.

http://researchbriefings.files.parliament.uk/documents/SN06852/SN06852.pdf

Rowthorn, B and Wayne, N (1988) Northern Ireland: The Political Economy of Conflict. Cambridge: Polity Press.

Scottish Government (2013) Annual report for the child poverty strategy for Scotland, September 2013.

http://www.scotland.gov.uk/Resource/0043/00432470.pdf

Scottish Government (2014) JSA Sanctions in Scotland: An analysis of the sanctions applied to claimants of Jobseeker's Allowance in Scotland.

http://www.scotland.gov.uk/Topics/People/welfarereform/analysis/Sanctions

Taylor-Gooby, P and Stoker, G (2011) 'The Coalition Programme: A New Vision for Britain or Politics as Usual?' The Political Quarterly 82(1): 4-15.

The Big Issue (2014) 'ATOS, Deaths and Welfare Cuts' 10 March.

http://www.bigissue.com/features/3637/atos-deaths-and-welfare-cuts

Tomlinson, M. (2002) 'Reconstituting Social Policy: the case of Northern Ireland', in Sykes, R., Bochel, C. and Ellison, N. (eds) Social Policy Review 14: Developments and Debates 2001-2002. Bristol: Policy Press. pp. 57-83.

Tomlinson, M and Kelly G (2011) 'Response to Northern Ireland's Draft Budget'. Poverty and Social Exclusion in the UK: Policy Response Series No. 6. http://www.poverty.ac.uk/pse-research/pse-uk/policy-response

Tomlinson, M (2012) 'War, peace and suicide: The case of Northern Ireland', International Sociology 27(4): 464-482.

Tomlinson, M. (2013) Legacies of Conflict: Evidence from the Poverty and Social Exclusion Survey, Knowledge Exchange Seminar Series, Northern Ireland Assembly, $24^{\text {th }}$ October. http://www.niassembly.gov.uk/Assembly-Business/Research-andInformation-Service-RalSe/Knowledge-Exchange/Knowledge-Exchange-SeminarsSeries-3/\#2

Tomlinson, M and Kelly, G (2013) 'Is everybody happy? The politics and measurement of national wellbeing', Policy and Politics 41(2): 139-157. 
Tomlinson, M, Hillyard, P and Kelly, G (2014) 'Child poverty in Northern Ireland: Results from the Poverty and Social Exclusion study' in Beneath the Surface: Child Poverty in Northern Ireland. Belfast: Child Poverty Alliance. pp. 11-34.

Varney Report (2007) Review of Tax Policy in Northern Ireland. HM Treasury.

Welsh Government (2015) Child Poverty Strategy for Wales, March 2015. http://gov.wales/docs/dsjlg/publications/150327-child-poverty-strategy-walesv2-en.pdf

Wiggan, J (2012) 'Telling stories of 21st century welfare: The UK Coalition government and the neo-liberal discourse of worklessness and dependency', Critical Social Policy 32(3): 383-405.

Work and Pensions Committee (2014a) The role of Jobcentre Plus in the reformed welfare system.

http://www.publications.parliament.uk/pa/cm201314/cmselect/cmworpen/479/47902.ht $\mathrm{m}$

Work and Pensions Committee (2014b) Employment and Support Allowance and Work Capability Assessments. First Report of Session 2014-15, HC 302.

Mike Tomlinson works at Queen's University Belfast where he is Professor of Social Policy and Head of the School of Sociology, Social Policy and Social Work. His main research interests lie in two main areas: economic and social marginalization, and social control. He has worked on unemployment, poverty and inequality, and has always been interested in how such problems affect specific communities, families and individuals. Much of his work has focused on the political economy of the Northern Ireland conflict and he is particularly interested in the role of social policy and social control strategies in managing division and conflict. He is a co-investigator on the Poverty and Social Exclusion in the UK project (ESRC Grant RES-060-250052). Recent publications include: Tomlinson, M, Hillyard, P and Kelly, G (2014) 'Child poverty in Northern Ireland: Results from the Poverty and Social Exclusion study' in Beneath the Surface: Child Poverty in Northern Ireland. Belfast: Child Poverty Alliance. pp. 11-34; Tomlinson, M and Kelly, G (2013) 'Is everybody happy? The politics and measurement of national wellbeing', Policy and Politics 41(2): 139-157. Address: School of Sociology, Social Policy and Social Work, Queen's University Belfast, University Road, Belfast BT7 1NN, Northern Ireland. email: m.tomlinson@qub.ac.uk

\section{Note}

1 This article is based on data collected for 'Poverty and Social Exclusion in the UK', ESRC Grant RES-060-25-0052. I wish to acknowledge the support provided by Dr. Demi Patsios, University of Bristol, in preparing and analysing the Northern Ireland dataset used in the article. 